\title{
Board Gender Diversity and Dividend Policy in Chinese Listed Firms
}

\author{
Qurat UI Ain', Xianghui Yuan' (D, Hafiz Mustansar Javaid², \\ Jinkai Zhao ${ }^{3}$, and Li Xiang'
}

\begin{abstract}
This study investigates the relationship between gender diversity on the board and dividend payouts in China using a large sample over the period 2003-2017. Our results provide robust and strong evidence showing that gender diversity on the board is positively associated with cash payments of dividends. The empirical outcomes confirm that gender diversity on the board facilitates corporate governance and subsequently promotes dividend payouts. We demonstrate that gender diversity on the board has the greatest effect when the board has critical mass participation (three or more female directors) compared with only their token participation. However, independent female directors increase dividend payouts, while female executive directors do not have a significant impact. Furthermore, we extend the literature on the relationship between dividend payments and government ownership by providing evidence that gender diversity has a higher impact on dividend payouts for state-owned enterprises than non-state-owned enterprises. After controlling the endogeneity problems, our findings are reliable and robust.
\end{abstract}

JEL classifications: G30, G35

\section{Keywords}

board gender diversity, dividend payouts, agency problem, corporate governance, female board directors, government ownership

\section{Introduction}

Recent studies reveal an upward trend for women's participation in the boards of U.S. public companies in the last decade (Catalyst, 2016). Conversely, the involvement of women in the boardroom is underrepresented worldwide (Catalyst, 2017; Institutional Shareholder Services, 2017). Within the context of best practices in corporate governance (CG), some countries (such as, Australia, the United Kingdom, and Canada) have recommend women's inclusion on corporate boards, whereas some countries in Europe (such as, France, Belgium, Spain, Norway, and Italy) have specified quotas on corporate boards for the proportion of female directors (Usman et al., 2018). In this regard, observers and regulators are still working toward greater participation of females in the boardroom (Adams \& Mehran, 2012). Based on global listed companies' statistics for 2016, approximately $11.7 \%$ of the average board of directors and $4.6 \%$ of their CEOs are female in globally listed companies. ${ }^{1}$ Recently, legislators in California passed a bill on 29 August 2018 that requires having at least one female director on the corporate board in all significant listed companies by the end of 2019. Any corporation failing to adopt this quota may face severe financial penalties (Ye et al., 2019). Due to these proposals and policies, the need to examine the benefits that are linked with corporate leadership and gender diversity is vital.

A body of theoretical literature connects dividend policy with the uncertainty of cash flow, investment opportunities, and ownership structure (Chay \& Suh, 2009; Denis \& Osobov, 2008; Fama \& French, 2001; La Porta et al., 2000). Jensen et al. (1992) and La Porta et al. (2000) asserted that governance quality may affect the policy of dividend payouts because dividend payouts are partly influenced by conflicts of interests between insiders of the firm and external shareholders. DeAngelo et al. (2006) stated that dividend payments reduce the free cash flow that is available for investments; this requires managers to acquire capital from external sources, imposes stricter regulations on management by external investors, and reduces agency problems. The improvement in dividend payment ratios may reduce

\footnotetext{
'Xi'an Jiaotong University, China

${ }^{2}$ Sapienza Università di Roma, Italy

${ }^{3}$ Shandong University of Science and Technology, Qingdao, China

Corresponding Author:

Xianghui Yuan, School of Economics and Finance, Xi'an Jiaotong

University, No.74, Yanta West Road, Xi'an 7I006I, China.

Email: xhyuan@mail.xjtu.edu.cn
} 
agency problems while financing restrictions are not strict (Chae et al., 2009). This demonstrates that an efficient governance mechanism will push for more dividend policies to overcome agency problems.

Most of the finance literature has examined the participation of female directors on the board as a business case (Adams \& Ferreira, 2009; Adams \& Mehran, 2012; Cumming et al., 2015; Liu, 2018; Post \& Byron, 2015; Rose, 2007). Some studies have proposed that heterogeneous boards have better performance compared with non-diverse boards (Carter et al., 2003; Erhardt et al., 2003; Joecks et al., 2013; Liu et al., 2014), better governance (Adams \& Ferreira, 2009), and increased market valuation (Campbell \& Minguez-Vera, 2007) and reduce agency problem (Ain et al., 2020). Gender socialization theory suggests that females are more caring, socially concerned, and more expressive (Carlson, 1972; Eagly \& Crowley, 1986; Gilligan, 1977). McGuinness et al. (2017) stated that these qualities help female directors and executives to manage the relationship with stakeholders. Besides this, female directors provide diverse opinions in the boardroom; due to diversity in the discussion, the dynamics of the board are improved and this enhances decision making (Erhardt et al., 2003; Gul et al., 2011; Miller \& Triana, 2009; Zahra \& Pearce, 1989). The findings of the above studies suggest that gender diversity on boards helps in making reasonable decisions and increases the tendency to promote the interests of shareholders by considering agency problems. As a result, there is an increased likelihood of dividend initiation and higher payout ratios for dividends.

On the basis of above arguments, some studies have examined the influence of female directors' participation on agency problems, for example, Jurkus et al. (2011), Chen et al. (2017), and Byoun et al. (2016) in the U.S. setting; Ain et al. (2020) and McGuinness et al. (2015) using Chinese data $^{2}$; Pucheta-Martinez and Bel-Oms (2016) using data for Spanish firms; Saeed and Sameer (2017) studying emerging economies $^{3}$; and Trinh et al. (2020) using U.K. data. These studies suggest that female participation on the board has an impact on dividend payouts but provide mixed results. Although these studies offer useful insights into the literature, their focus is on developed countries, with little consideration paid to developing countries. In general, developing countries have different regulatory environments compared with developed countries (Beck \& Levine, 2004; La Porta et al., 2000). The debate on agency problems in developed countries is also relevant in developing countries. Some institutional settings, for example, monitoring shareholders' rights and government ownership of emerging economies, however, are different from developed markets. Therefore, these diverse market characteristics may affect decisions regarding dividend payouts differently.

Using 29,104 observations of Chinese listed firms from 2003 to 2017, we analyze the influence of board gender diversity on dividend payout policy. Our results provide strong and robust evidence that the participation of female directors in the boardroom positively affects decisions regarding dividend payouts, and that independent female directors have more effect as opposed to female executive directors. Our results also suggest that the critical mass of female directors plays an important role on corporate boards, having more impact on dividend decisions when there are three or more female directors on the board. Furthermore, our study reports higher positive relationship between the participation of female directors and dividend payouts in state-owned firms. All of our findings are in line with the opinion that female participation on the board promotes CG and also uses the dividend payment policy as a tool in the reduction of agency cost.

This study provides several contributions to the literature. First, going beyond the studies of developed countries, our research provides evidence from the largest emerging economy in the world, China. Our research adds value to the literature on gender diversity, which mainly focuses on the business case for gender heterogeneity by examining the influence of gender diversity on firm's dividend payouts. This article provides evidence of a strong positive association between female directors on the board and dividend payouts. Second, compared with previous studies, which have mainly focused on the institutional settings of developed countries (Byoun et al., 2016; Chen et al., 2017; Pucheta-Martinez \& Bel-Oms, 2016), China has a different institutional setting. Therefore, it is important to study how a diversified board, with female directors, affects dividend payments in a different business environment. We consider the unique institutional factors of China while examining the governance role of female directors and dividend payouts. Our study extends the prior literature by investigating how institutional variations within the country affect the governance role of female directors on decisions regarding dividend payouts. The distinctive nature of Chinese ownership structure affects its institutional environment, shareholder protection, and CG effectiveness (Shleifer \& Vishny, 1997). Thus, we contribute to institutional theory by providing novel evidence in China that gender diversity has a greater impact on the dividends payouts of state-owned enterprises (SOEs) than non-state-owned enterprises (nonSOEs) and that dividend payments increase with state ownership.

Third, critical mass theory proposes that female directors have more effect on the board when there are three or more (Kanter, 1977; Kristie, 2011). Liu et al. (2014) and Gyapong et al. (2016) also reported that a critical mass of females has the most significant impact on firm performance. Our study provides evidence that when the number of female increases from one to two, and from two to three, this results in more dividend payouts. These results suggest that when three or more female directors are involved on the board, they have greater ability to improve dividend payouts and free up corporate resources from the control of 
insiders. Finally, we study whether independent and executive female directors demonstrate the same governance role in increasing dividend payouts. Our results report that only independent female directors significantly increase the dividend payouts, while executive female directors have an insignificant impact on dividends. This outcome contributes the literature by providing new insights regarding the governance role of females. Some previous studies have overlooked this question regarding whether executive and non-executive female directors have an equal effect on effective monitoring (Adams \& Ferreira, 2009; Gul et al., 2011; Nielsen \& Huse, 2010).

The rest of the article is organized as follows: The next section defines the institutional background of China, followed by the "Theoretical Background" section. Details regarding hypothesis development are provided in the "Hypothesis Development" section, followed by the details of the empirical research design. Then the empirical results are reported, followed by details concerning endogeneity problems in "Endogeneity" section and robustness tests in the following section. Conclusions are provided in the last section.

\section{Institutional Background of China}

In Shenzhen in 1990 and in Shanghai in 1991, China allowed stock markets to open mainly to collect capital for the state and for state-controlled enterprises (SOEs), and the state continues to dominate much of the corporate economy (Areddy et al., 2008; Wang et al., 2011). The "structure of split shares" is well known in Chinese companies, through which two stock classes are traded publicly and two classes are not traded publicly. The publicly listed stocks include "A" and "B" shares. The A shares are denominated in renminbi, while B shares are denominated in Hong Kong Dollars (HKD) and in U.S. dollars. About two thirds of listed companies' shares are not tradable. Among the non-tradable shares, about half are "legal person" shares, held by other Chinese companies, SOEs, or non-bank financial entities. The remaining non-tradable shares are state-owned shares, directly held by central or local government departments, or held by SOEs.

The majority of listed firms in Latin American, Western, and Asian countries (except China) are controlled and owned by financial institutions, individuals, and wealthy families (Morck \& Steier, 2005). In these countries, the state has nothing to do with the ownership of corporations in most cases, but this situation is different in China. The Chinese economy is the second largest economy in the world, but compared with Anglo-Saxon countries (e.g., the United States, Australia, and the United Kingdom), China is viewed as a transitional and new economy with distinctive features. Several studies have used the Anglo-Saxon environment to explain their concepts and conduct their research (Gulzar et al., 2019).
Li and Zhang (2010) provided evidence that the state serves as the sole controller and controls over $63.5 \%$ of entities' ownership in China. Firth et al. (2016) reported that most firms in China provide little room for individual investors to influence corporate decisions. Based on state directives, the government (the fundamental controlling shareholder of most firms) is in more favor of cash dividend distributions to reduce free cash flows in firms and control managers' preferences. ${ }^{4}$ Alternatively, private-owned firms face less political pressure and face more capital constraints in obtaining external equity and long-term debt compared with SOEs. Private-controlled firms depend on internal financing and distribute lower cash dividends. According to these arguments, dividend payments increase with state ownership (Bradford et al., 2013; Wang et al., 2011); their findings are consistent with agency theory regarding dividend policy in that dividend payments allow the state to obtain disproportional benefits from firms. ${ }^{5}$

In the past two decades, the Chinese stock market has undergone some dramatic changes. The percentage of dividend-paying firms increased from $50.92 \%$ in 2003 to $80.73 \%$ in 2017, as shown in Figure 1. The considerable percentage of government ownership in SOEs differentiates them from non-SOEs. Hence, it is important to study the cash dividend issues of Chinese listed firms.

\section{Theoretical Background}

In CG, the growing research on gender diversity has received increasing attention (Pucheta-Martinez \& Bel-Oms, 2016). Some previous studies (Jensen, 1986; Rozeff, 1982) have emphasized agency theory by analyzing the impact of dividend policy when there is a conflict of interest within the organization. Agency cost may be caused by asymmetric information between managers and shareholders; hence, it emerges as an agency problem. This situation makes investors more conscious and suspicious of future cash flows (Jensen \& Meckling, 1976).

Grossman and Hart (1980) analyzed the way in which dividend payments mitigate agency problems by reducing free cash flows in companies. The dividend policy has been asserted to be a device for CG and, more precisely, a way of mitigating Jensen's (1986) free cash flow problem, which thus reduces agency costs (Rozeff, 1982). Dividend payouts, debt-financing, and managerial equity ownership are noted as an effective mechanism to overcome agency problems in firms (Bathala \& Rao, 1995).

Rozeff (1982) stated that dividend payouts are considered a mechanism for monitoring firms. Carter et al. (2010) asserted that the participation of female directors on boards leads to powerful control mechanisms because their presence increases the board independence and they tend to ask more questions. Kandel and Lazear (1992) showed that gender diversity functions, such as a "watchdog" for shareholders, might also improve joint monitoring. Hence, female 


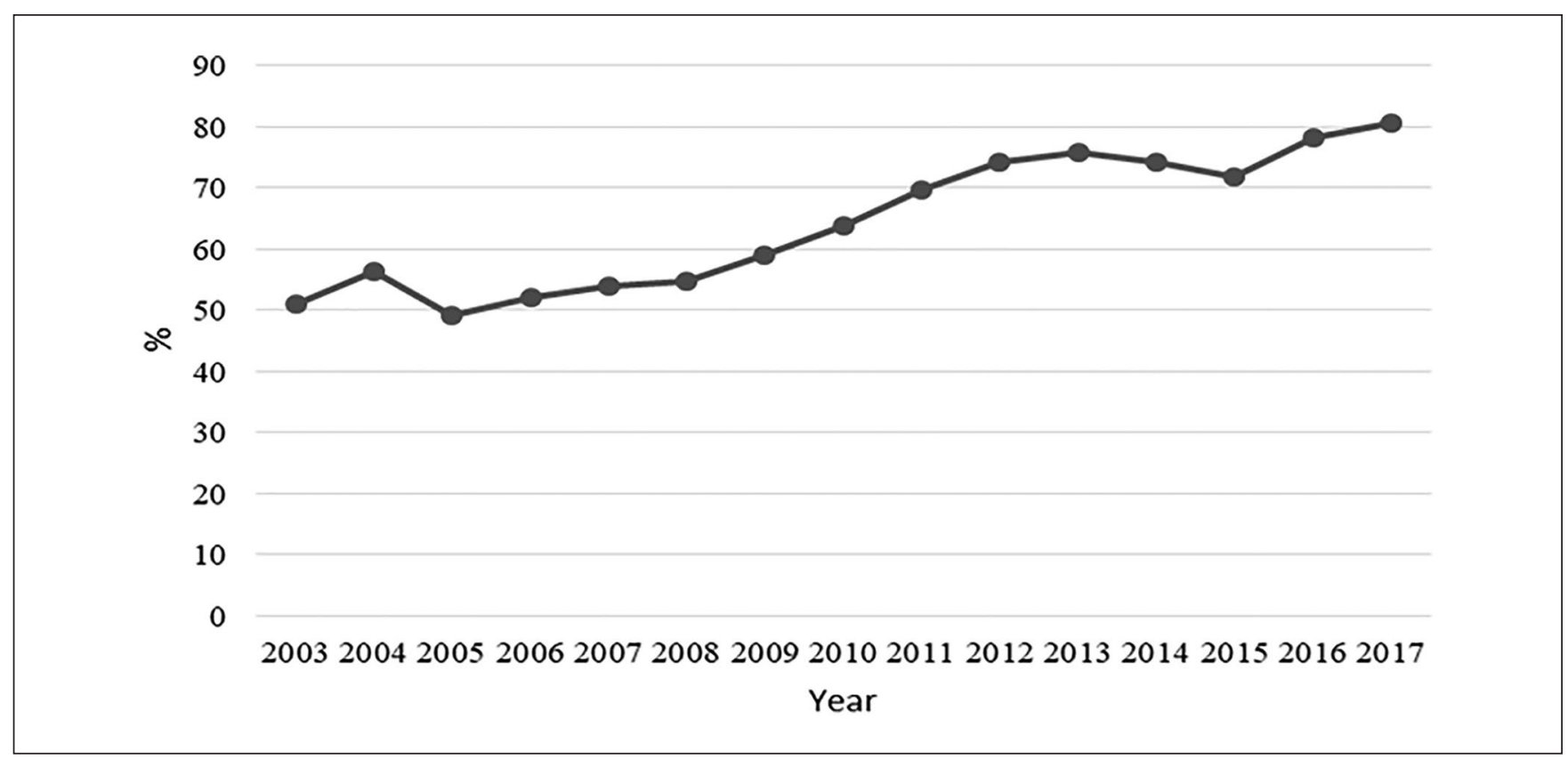

Figure I. Percentage of listed firms paying cash dividends (2003-20I7).

directors on the board decrease agency problems concerning free cash flows as they are inclined to pay more dividends, thus leading to more incentives between managers and shareholders. Kandel and Lazear (1992) supported these views and stated that board gender diversity is associated with lesser holdings of cash and higher dividend payments. Byoun et al. (2013) demonstrated that women's participation on boards reduces the problems of free cash flow and increases dividend payouts.

\section{Hypothesis Development}

\section{Board Gender Diversity and Dividend Payouts}

A significant function of $\mathrm{CG}$ is to monitor and resolve the agency problems that originate from conflicts of interest between shareholders and managers (Fama, 1980; Fama \& Jensen, 1983; Jensen \& Meckling, 1976). Agency problems connected with conflict of interests may comprise extra salaries and perquisites' consumption by insiders (Jensen \& Meckling, 1976); willingness to pursue firm growth such as developments unable to provide any benefit to external shareholders (Grossman \& Hart, 1986); and the propensity to invest earnings in investments that are suboptimal (Jensen, 1986). La Porta et al. (2000) reported that, in line with the conflicts mentioned above, shareholders prefer to disgorge cash flows through dividend payments, because outside shareholders think that corporate insiders may use the extra cash for their own benefits or may invest inefficiently. The policies for dividend payments can be used as an essential mechanism for solving agency problems (Brav et al., 2005; Easterbrook, 1984). Academic literature also indicates that the board's heterogeneity gives rise to more efficient and operative governance mechanisms (Adams \& Ferreira, 2009; Hillman et al., 2007), that firms that have a high proportion of female non-executive directors are more inclined to pay dividends (Chen et al., 2017). Levit and Malenko (2016) also reported that gender heterogeneity may be able to promote dividend payments by protecting the interests of shareholders and improving governance mechanisms.

Furthermore, women directors are considered good monitors that strengthen the rights of shareholders. In this situation, shareholders force managers to pay more dividends. Previous literature from advanced countries provides support for the monitoring role of female directors. For instance, Byoun et al. (2016), using U.S. corporations, and Pucheta-Martinez and Bel-Oms (2016), using Spanish firms, found that dividend payouts and gender heterogeneity are positively related with each other. Bae et al. (2012) asserted that a strong CG mechanism in firms is related to higher dividend payments and mitigates agency problems. Trinh et al. (2020) also demonstrated a positive relationship between gender diversity and dividend payments. Finally, McGuinness et al. (2015) provided positive but insignificant results in this context, while Mustafa et al. (2020) showed negative relationship between gender diversity and dividend announcements.

Diversity on the board affects its efficiency at different levels, for example, the individual level and the team level. For instance, women directors are more focused on participating in monitoring (Adams \& Ferreira, 2009), are more sensitive to difficult issues (Gul et al., 2011), and are more likely to follow the rules and regulations than men (Bernardi 
\& Arnold, 1997). Collectively, all the above studies suggest that female directors are more likely to follow the rules, are more sensitive to corporate issues, and are more focused on solving agency problems by increasing the efficiency of the governance mechanism and are more motivated to promote shareholders' interest at the individual level. Liu (2018) indicated that greater participation by female directors on the board leads to fewer lawsuit risks, and partly favors dividend payouts. Hence, we suppose that female directors are more likely to pay dividends at the individual level.

Previous literature shows that the participation of females at the team level is more likely to solve complicated problems. Niederle and Vesterlund (2007) and Agarwal et al. (2016) reported that female directors adopt a style of leadership that portrays collaboration and trust, because this trust helps in the exchange of productive information between board directors and the corporation. Gul et al. (2011) stated that board gender diversity provides different points of view and promotes the corporate board decision-making style. All above studies suggest that gender heterogeneity provides a wide range of views by incorporating different perspectives, which ultimately results in better decisions, potentially including those decisions that are taken for the betterment of shareholder interest and to solve agency problems. Thus, from team-level perspective, we suppose that more diversity on boards is positively connected with more dividend payouts. Thus, we hypothesize the following:

Hypothesis 1 (H1): Board gender diversity positively affects the dividend payouts.

The board's monitoring tendency depends on its independence (Chen et al., 2015; Osma, 2008). Bugeja et al. (2016) and Adams and Ferreira (2009) reported that the independence of directors can be calculated as the percentage of the boards' non-executive directors. Independent directors on the board are engaged more in a monitoring function than executive directors. Chen et al. (2017) asserted that, due to this effective monitoring, the payments of dividends are also increased. Fama and Jensen (1983) reported, from an agencytheory standpoint, that independent non-executive directors resolve agency conflicts between the agent and principal. Empirical literature proposes that non-executive directors enhance the transparency of the firm (Knyazeva et al., 2013) and help to reduce managerial misappropriation (SetiaAtmaja, 2010). These results show that independent directors are more likely to free up firm resources from the hands of insiders by increasing dividend payments than executive directors (Pucheta-Martinez \& Bel-Oms, 2016).

Previous literature provides mixed outcomes on the relationship of executive versus independent directors with dividend payouts; for example, Saeed and Sameer (2017) found a negative relationship, Chen et al. (2017) found a positive relationship, while Pucheta-Martinez and Bel-Oms
(2016) found no effect. On the other hand, Nekhili et al. (2020) and Lai et al. (2017) reported that women directors exhibit less opportunistic behavior and are more likely to increase dividend payouts (Hunter \& Sah, 2014). Related to this point, if female directors are considered less opportunistic, then they tend to increase dividend payouts. From the above discussion, we suppose that both female independent directors and female executive directors may affect dividend payouts positively. However, we expect that this relationship is stronger for female independent directors because of their independence. Based on the above studies, we hypothesize the following:

Hypothesis 2 (H2): The board gender diversity and dividend payouts relationship is stronger for female independent directors than female executive directors.

The critical mass of female may also have a significant effect on the firm-level performance of corporations (Glazer \& Kristol, 1976). Kanter (1977) reported that, due to maledominated boards, the achievements of female directors were downplayed, leading to their low participation. Spangler et al. (1978) asserted that, due to the minority of women directors on boards, the pressure of performance, the communication gap, and role entrapment, the achievements of females on the board are diminished. Following critical mass theory, Kramer et al. (2007) proposed that female directors are considered more powerful when there are three or more on boards. Kristie (2011) recommended that the participation of one female director on board is token, two is presence, and three or more become voice. Gyapong et al. (2016) and Liu et al. (2014) provided evidence that when the participation of female directors on the board is high, they can significantly affect firm performance and value. Based on the above, we hypothesize the following:

Hypothesis 3 (H3): The relationship between gender diversity and dividend payouts is stronger for female directors' critical mass participation than token participation.

In most listed firms in emerging markets (such as China), the government retains the rights of controlling shareholders, unlike Western countries (Saeed \& Sameer, 2017). Based on an OECD report, Buge et al. (2013) revealed that the percentage of government ownership percentage is extremely high in BRIC countries compared with other developed and developing countries. Some studies have illustrated that SOEs have high dividend payments compared with private firms (Bradford et al., 2013; Firth et al., 2016; Wang \& Shailer, 2012). Blanchard and Shleifer (2000) reported that state-owned firms obtain advantages in terms of governance and unique commercial treatment. Due to this homogeneity in state ownership, firms that are owned by the state are considered to have an unusual relationship with government 
banks. Accordingly, we argue that it is easier for state-owned firms to obtain finance, which mitigates unpredictability for Chinese listed firms.

Agency theory also provides support for the positive association between gender diversity and dividend payouts in SOEs of developing countries. Ben-Nasr, (2015) and Bradford et al. (2013) asserted that SOEs are more likely to suffer agency problems compared with non-SOEs. They identified two sources of agency problems; the first source is disagreements between controlling shareholders and managers, and the second source is the objective differences between politicians and firm owners (Menozzi et al., 2012). Jonge (2014) proposed that some empirical studies provide evidence for improving the governance structure of firms; SOEs are under pressure to increase the participation of females in boardrooms. SOEs may give an indication to society regarding the administrative efficiency and better governance system of state-run firms and are likely to serve as "model enterprises" (Saeed et al., 2016). To overcome agency problems, dividend payments are considered a crucial mechanism that gender-diverse boards can adopt. Therefore, we can hypothesize that gender-diverse boards are more likely to choose high dividend payouts in Chinese firms with government ownership, characterized by severe agency problems. Based on the above arguments, we hypothesize the following:

Hypothesis 4 (H4): Board gender diversity has a higher impact on the dividend payments of SOEs as compared with non-SOEs.

\section{Empirical Research Design}

\section{Study Sample}

We acquired all the data from the China stock market and research database (CSMAR) for all A-share listed companies on the Shanghai and Shenzhen stock exchanges for the sample period (2003-2017). We chose China as our sample for several reasons. According to the World Trade Organization (2015), China's rapid growth rate makes it the best representative of emerging markets. China is a key player in the global economy because of its human resources, rapid growth, and its share in world trade. Finally, state ownership is the major form of corporate ownership in China. Therefore, this country provides us with a better platform to study the influence of government ownership on firms' financial decisions (e.g., dividend policy). We excluded all financial companies from our sample because their features are unique to these firms, which may bias our results (Liu et al., 2014; Sila et al., 2016). We also excluded all firms whose net profits exceeded their sales. These steps provided us a final sample of 29,104 firm-year observations from 2003 to 2017. The details of the complete sample are provided in Table A1 across year and industry. The number of observations increases over time, which is consistent with China's market growth share and consistent with (Du, 2014) and He and Luo (2018).

\section{Variable Measurement}

Our study examines the influence of gender diversity on the dividend payouts of Chinese listed firms. By following Adams and Ferreira (2009), Chen et al. (2017), and Liu et al. (2014), FEMALE is calculated using the percentage of female directors $(F D P)$, dummy of female directors $(F D D)$, percentage of female independent directors $(F I D)$, percentage of female executive directors $(F E D)$, female dummy $(F D 1)$ for having one female, $F D 2$ for having two females and FD3 for having three of more females on the board. We have also used some other measures of gender diversity for robustness tests.

DIVIDEND is used as the dependent variable. Our study uses dividend payout ratio measured by total dividend to net income $(D I V P R)$ as the first dependent variable, in line with Bradford et al. (2013) and Saeed and Sameer (2017). Our second measure is the total amount of dividends to total assets of the firm (DTA) (Chen et al., 2017). In the robustness analysis, we adopted two other measures of dividend payouts: dividend dummy $(D D)$; and dividends over sales $(D S A L)$.

On the basis of the literature, we included different control variables. $B D I$ is the independence of the board and is measured as the proportion of independent directors. $B D S$ is measured as the total number of directors on the board. Pucheta-Martinez and Bel-Oms (2016) reported that board size and dividend payments are positively associated. Firm performance is also a control variable (TOBINQ and $R O A)$, measured as market value over total assets and net income over total assets, respectively. Byoun et al. (2016), Chay and Suh (2009), and Lintner (1956) reported a positive association between firm performance and dividend payments. FSIZE is measured as the natural log of total assets, and it defines the firm size. Previous studies have shown that firm size has a positive relation with dividend payments (Denis \& Osobov, 2008; Fama \& French, 2001). We also use LEV as a control variable, which is calculated as the total debt of the firm over total assets. We expect a negative relationship between leverage and dividend payments. Jensen et al. (1992) asserted that firms that are highly leveraged are likely to pay less dividends because they need internal cash for the payment of debts to creditors. RETA measures the ratio of retained earnings over total assets (Byoun et al., 2016; DeAngelo et al., 2006). We also include $F C F$, which is the free cash flow position of the firm and has a positive association with dividend payouts (Adjaoud \& Ben-Amar, 2010). Finally, dividend payouts may differ through industries and years; to control this, we include year and industry dummies in all regressions. A detailed description of all the variables is presented in Table 1 . 
Table I. Variable Measurement.

\begin{tabular}{|c|c|}
\hline Variable & Definition \\
\hline \multicolumn{2}{|c|}{ Dependent variables } \\
\hline DIVPR & Total dividend over net income \\
\hline DTA & Dividends in cash over total assets \\
\hline$D D$ & If the company distributes dividends, the dummy variable is equal to I; otherwise it is zero \\
\hline DSAL & Dividends in cash over sales \\
\hline \multicolumn{2}{|c|}{ Independent variables } \\
\hline FDP & The percentage of female directors on the board to board size \\
\hline FDD & Dummy variable is equals to $I$ if the board has at least one female; otherwise it is zero \\
\hline FID & Percentage of independent female directors on the board to board size \\
\hline FED & Percentage of female executive directors on the board to board size \\
\hline FNUM & Total number of female directors on the board \\
\hline LFNUM & Lag of the total number of female directors on the board \\
\hline FCEO & Dummy variable, if the CEO is a woman, is equal to I; otherwise it is zero \\
\hline LFCEO & Dummy variable, if the CEO is a woman in $t-I$ year, is equal to $I$; otherwise it is zero \\
\hline FBI & Blau index: $I-\sum_{i=1}^{n} P_{i}^{2}$, where $P_{i}$ is the percentage of each category and $n=2$ (male and female) \\
\hline FSI & Shannon index: $-\sum_{i=1}^{n} P_{i} \ln P_{i}$, where $P_{i}$ is the percentage of each category and $n=2$ (male and female) \\
\hline FDI & Dummy variable is equals to $I$ if the board has only one female; otherwise it is zero \\
\hline FD2 & Dummy variable is equals to $I$ if the board has two females; otherwise it is zero \\
\hline FD3 & Dummy variable is equals to $I$ if the board has three or more than three females; otherwise it is zero \\
\hline \multicolumn{2}{|r|}{ 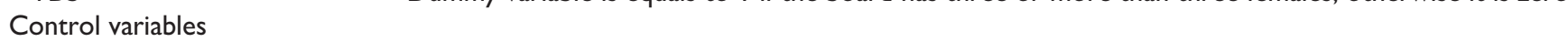 } \\
\hline \multicolumn{2}{|c|}{ Corporate governance (CG) variables } \\
\hline BDS & Total number of directors on the board \\
\hline$B D I$ & Total number of independent directors on the board over board size \\
\hline CEOT & Number of years as CEO \\
\hline CEOD & If the CEO is also the Chairman of the Board, the CEO duality is equal to I, otherwise zero \\
\hline \multicolumn{2}{|c|}{ Financial variables } \\
\hline ROA & Net income over total assets \\
\hline TOBINQ & Market value over total assets \\
\hline LEV & Total debt (short + long term) over total assets \\
\hline RETA & Retained earnings of the firm over total assets \\
\hline FSIZE & Logarithm of total assets \\
\hline FGROW & Change in the total assets of the firm \\
\hline FCF & Free cash flow position of the firm \\
\hline
\end{tabular}

\section{Estimation}

To analyze the relationship between gender diversity and dividend payouts, we ran least square regressions. Numerous studies on gender diversity and dividend payments (Chen et al., 2017; Dezhu et al., 2019; McGuinness et al., 2017) have employed the same method to analyze the results. The model specification is as follows:

$$
\begin{aligned}
\text { DIVIDEND }_{i t} & =\alpha+\beta_{1} F E M A L E_{i t}+\beta_{2} L E V \\
& +\beta_{3} \text { TOBINQ+ } \beta_{4} \text { ROA }+\beta_{5} B D S \\
& +\beta_{6} B D I+\beta_{7} C E O D+\beta_{8} C E O T \\
& +\beta_{9} \text { RETA }+\beta_{10} F S I Z E+\beta_{11} \text { GROWTH } \\
& +\beta_{12} F C F+\sum \text { industry }_{t}^{i}+\sum \text { year }_{t}^{i}++\varepsilon_{i t},
\end{aligned}
$$

where the dependent variable is DIVIDEND ${ }_{i t}$ (measured by DIVPR and DTA), Eindustry ${ }_{t}^{i}$ is the industry fixed effect, $\Sigma$ year $_{t}^{i}$ is the year fixed effect, and $\varepsilon$ is the error term.

\section{Empirical Analysis}

\section{Descriptive Statistics}

Table 2 presents the details of the statistics, which include observations, mean, median, 25th quartile, median, and 75 th quartile. Analysis shows that $68.1 \%$ of firms pay a cash dividend, and $12.8 \%$ of directors are female across the sample. The percentage of independent and executive directors is only $5.2 \%$ and $7.6 \%$. Besides this, FD1, FD2, and FD3 have $36.9 \%, 20.1 \%$, and $7.8 \%$ means, respectively. This is consistent with Nguyen et al. (2013). Further variables demonstrate the appropriateness of the sample. For instance, the size of the firm is 21.796 , board size on average is 8.917 , and $36.7 \%$ of board directors are independent.

We also compare the characteristics of firms having female directors (diversified board) with those that do not have female directors on board (non-diversified board) in un-reported results. ${ }^{6}$ In a nutshell, firms having female directors on boards are associated with significantly higher dividend payments as compared with firms that do 
Table 2. Descriptive Statistics.

\begin{tabular}{|c|c|c|c|c|c|}
\hline Mean & $M$ & $S D$ & $\mathrm{P} 25$ & Median & P75 \\
\hline DIVPR & 0.113 & 0.205 & 0 & 0.05 & 0.15 \\
\hline DTA & 0.014 & 0.020 & 0 & .007 & 0.018 \\
\hline$D D$ & $0.68 I$ & 0.466 & 0 & 1 & 1 \\
\hline DSAL & 0.028 & 0.047 & 0 & 0.012 & 0.035 \\
\hline FDP & 0.128 & 0.122 & 0 & 0.111 & 0.222 \\
\hline FDD & 0.673 & 0.469 & 0 & 1 & 1 \\
\hline FNUM & 1.113 & 0.053 & 0 & I & 2 \\
\hline FID & 0.052 & 0.076 & 0 & 0 & 0.111 \\
\hline FED & 0.076 & 0.106 & 0 & 0.061 & 0.125 \\
\hline FCEO & 0.057 & 0.231 & 0 & 0 & 0 \\
\hline FDI & 0.369 & 0.482 & 0 & 0 & I \\
\hline FD2 & 0.201 & 0.401 & 0 & 0 & 0 \\
\hline FD3 & 0.078 & 0.268 & 0 & 0 & 0 \\
\hline$F B I$ & 0.193 & 0.159 & 0 & 0.198 & 0.346 \\
\hline FSI & 0.306 & 0.235 & 0 & 0.349 & 0.53 \\
\hline$B D I$ & 0.367 & 0.327 & 0.333 & 0.333 & 0.4 \\
\hline$B D S$ & 8.917 & 0.446 & 8 & 9 & 9 \\
\hline LEV & 0.514 & 0.155 & 0.279 & 0.446 & 0.609 \\
\hline TOBINQ & 4.71 & 1.848 & $1.37 \mid$ & 1.948 & 3.03 \\
\hline$R O A$ & 0.156 & 0.055 & 0.027 & 0.052 & 0.083 \\
\hline CEOT & 2.916 & 0.425 & 0.917 & 2 & 3.833 \\
\hline CEOD & 0.237 & 0.839 & 0 & 0 & 0 \\
\hline RETA & 0.318 & 37.518 & 0.071 & 0.141 & 0.221 \\
\hline FSIZE & 21.796 & 1.328 & 20.876 & 21.641 & 22.527 \\
\hline FGROW & 0.514 & 4.739 & 0 & 0.1 & 0.25 \\
\hline FCF & 0.716 & 0.655 & 0.319 & 0.552 & 0.885 \\
\hline
\end{tabular}

Note. This table presents the descriptive statistics of variables. For details of all variables, see Table I.

Table 3. Difference and Differences Test for Firms That Pay Dividends Compared with Those That Do Not.

\begin{tabular}{lcccccc}
\hline & \multicolumn{2}{c}{ Dividend $=$ Yes } & & \multicolumn{2}{c}{ Dividend $=$ No } & \\
\cline { 2 - 3 } Variable & $D D=1$ & $M$ & & $D D=0$ & $M$ & Difference \\
\hline FDP & 19,808 & 0.128 & & 9,296 & 0.110 & $0.018^{* * * *}$ \\
FDD & 19,808 & 0.68 & & 9,296 & 0.658 & $0.022^{* * * *}$ \\
FID & 19,808 & 0.056 & & 9,296 & 0.027 & $0.029 * * *$ \\
FED & 19,808 & 0.073 & & 9,296 & 0.082 & -0.009 \\
FDI & 19,808 & 0.369 & & 9,296 & 0.367 & $0.003^{* * * *}$ \\
FD2 & 19,808 & 0.205 & & 9,296 & 0.194 & $0.011^{*} *$ \\
FD3 & 19,808 & 0.081 & & 9,296 & 0.072 & $0.009 * * *$ \\
\hline
\end{tabular}

Note. This table shows the difference and differences test for firms that pay dividends as compared with firms that do not. Variables are as defined in Table I.

$*$, **, and $* * *$ indicate significance at the $10 \%, 5 \%$, and $1 \%$ levels, respectively.

not in both dividend measures. In addition, when it comes to the characteristics of $\mathrm{CG}$, the picture is quite mixed. Diversified firms tend to have a higher proportion of independent directors and are therefore more probable to have duality. Diversified firms are more likely to have larger board size, firm size, and firm growth but smaller CEO tenure.

Table 3 presents the distribution of female directors in relation to whether the firm pays a dividend or not. The results show that the difference of $F D P$ in dividend-paying and non-dividend paying firms is 0.019 , which is positive and significant at the $1 \%$ level. These results are consistent with our main findings and demonstrate a positive association between female directors and dividend payouts.

To check multicollinearity, we performed a Pearson correlation coefficient test among all the variables of the main regression, and the outcomes are reported in Table 4 . According to the literature for the acceptable magnitude of correlation, a correlation level of 0.8 or more creates the problem of multicollinearity (Field, 2005). Similarly, Liu et al. (2014) report that a value of 0.7 is a sign of multicollinearity. The findings in Table 4 reveal some high correlations (highlighted). However, this high correlation is among the dependent variables and gender-diversity variables, which are used alternatively in separate regressions. Furthermore, we also performed variance inflation factor (VIF) test to recheck this issue. ${ }^{7}$ Based on these outcomes, we conclude that our study has no multicollinearity issues.

\section{Regression Analysis}

Table 5 presents the results of main regression. We used least squares regression, following Chen et al. (2017). The results in Table 5, Columns 1 and 3, where the explained variable is dividend payout ratio, show that gender diversity measures on the board increase dividend payouts and that they have a positive association $(F D P=.045, t$-stat $=4.167$ and $F D D=$ $0.009, t$-stat $=3.335)$. These results are matched with the results in Columns 2 and $4(F D P=0.004, t$-stat $=3.402$ and $F D D=0.001, t$-stat $=2.736$ ), where the dependent variable is divided over total assets. These values are significant at the $1 \%$ level and support H1. The participation of female directors on the board improves its monitoring in two ways (Adams \& Ferreira, 2009; Gul et al., 2008). First, through distinctive cognitive and psychological features, female directors may improve the monitoring of boards. These characteristics differentiate their decision-making capabilities from those of their male counterparts (Man \& Wong, 2013; Pucheta-Martinez \& Bel-Oms, 2016). Second, female directors create intra-director monitoring, improving male directors' monitoring behavior (Adams \& Ferreira, 2009; Kandel \& Lazear, 1992) and efficiency. As a result, dividend payouts increase, and agency conflicts are reduced (Byoun et al., 2016; Chen et al., 2017). Jensen and Meckling (1976) postulated that efficacy in the monitoring of the board may reduce managerial rent-seeking behavior, and this outcome is consistent with agency theory.

Regarding the control variables, $B D S$ positively influences the dividend policy, which is in line with Chen et al. (2017). On the other hand, $L E V$ shows significant negative 


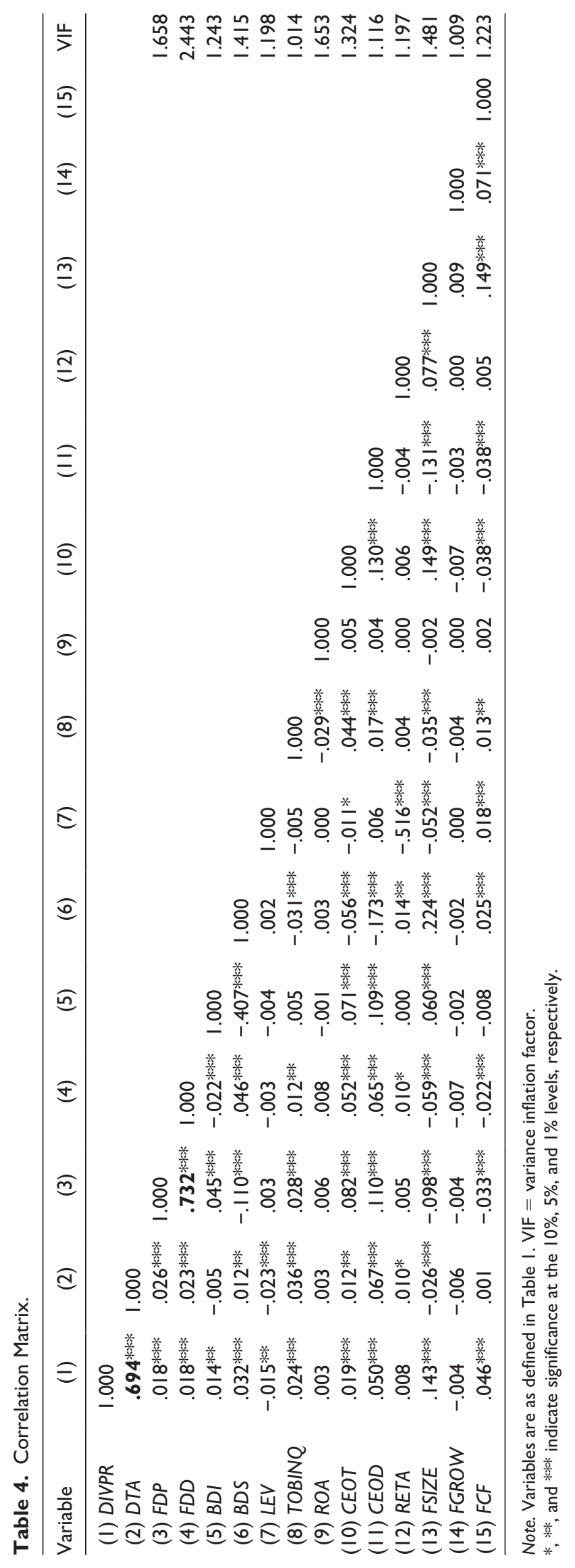




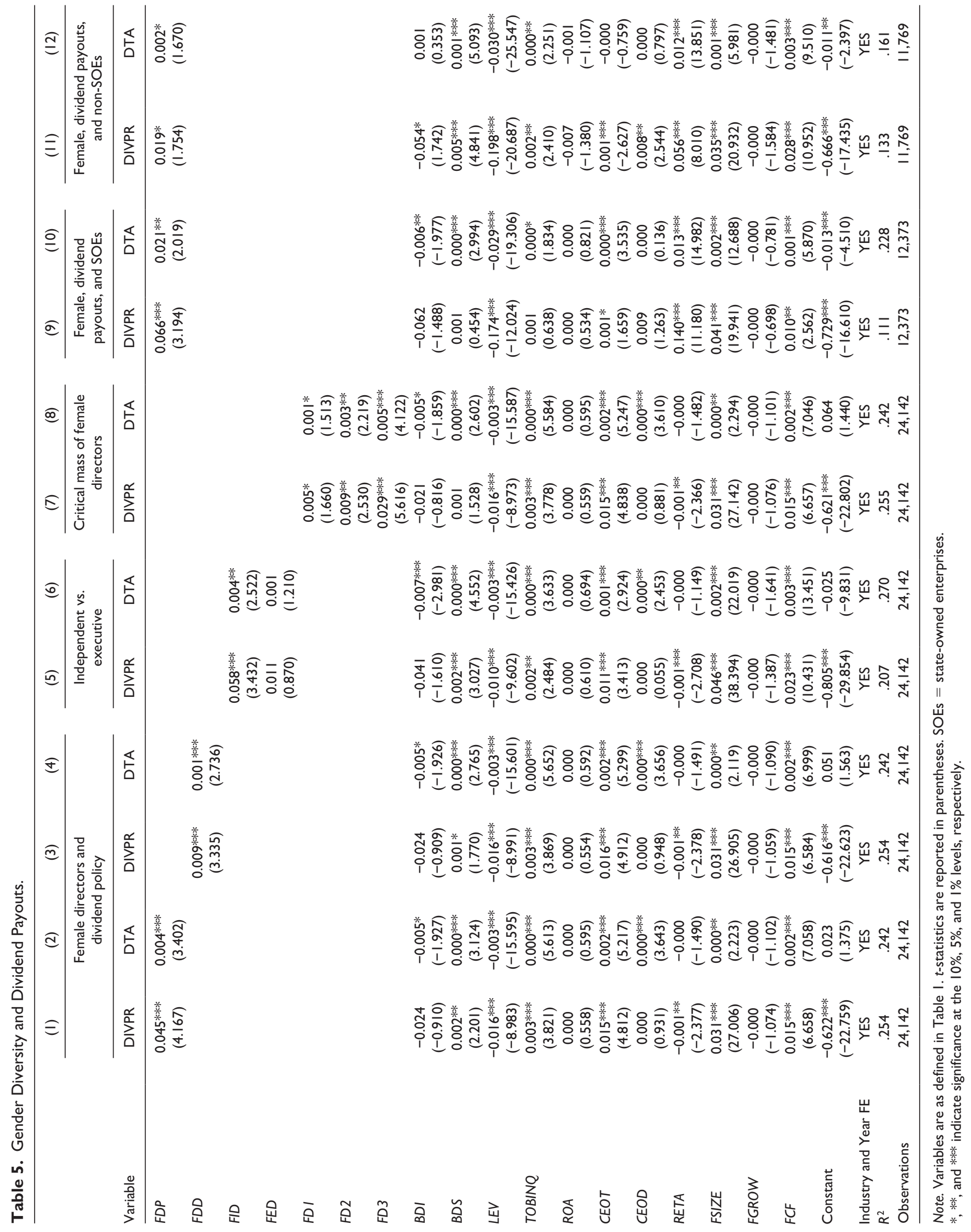


results. Debt and a high payout policy are both ways to mitigate Jensen's (1986) free cash flow problem, and $L E V$ 's negative sign is thus understandable (see Benito \& Young, 2003). TOBINQ has a significant positive effect on dividend payouts (Ye et al., 2019). CEOT also shows positive significant results. The relationship between FSIZE and dividend payouts shows a positive effect (Denis \& Osobov, 2008) which demonstrate that large companies have more net income, thereby providing conditions for paying dividends and, are more likely to reduce the agency cost, and thus prefer to adopt dividend distributions as a way of reducing agency problems (Ye et al., 2019).

Next, to test $\mathrm{H} 2$, we re-estimated the female directors and dividend payout relationship by dividing female directors in two groups: (a) female independent directors FID; and (b) female executive directors $F E D$ and re-run the regression. The findings are presented in Table 5 (Columns 5 and 6) and indicate that, by using $D I V P R$, independent female directors have positive significant results $(F I D=0.058, t$-stat $=$ 3.432 ), while FED has positive insignificant results (FED = $0.011, t$-stat $=0.870$ ). These findings are consistent when we used DTA as the dependent variable (FID $=0.004$, $t$-stat $=2.522)$ and $(\mathrm{FED}=0.001, t$-stat $=1.210)$. These findings support $\mathrm{H} 2$ and demonstrate that gender diversity on board increases dividend payouts by having women independent directors on the board, this effect becomes more pronounced. The findings also suggest that female independent directors have more incentives to decrease confiscation through freeing up resources from insiders' hands (Easterbrook, 1984). The results in Table 5 provide relatively strong evidence of women independent directors' positive impact and insignificant evidence of women executive directors' positive impact on dividend payouts. Generally, our findings indicate that the positive impact of female directors on dividend payouts mainly comes from the monitoring effect of female independent directors rather than the executive effect of female executive directors. Our findings are compatible with Chen et al. (2017), who also found positive results between independent female directors and dividend payouts, but inconsistent with Pucheta-Martinez and Bel-Oms (2016). The main reason for this difference is the institutional settings of both countries.

Next, we examined the critical mass theory postulation that having more female directors on the board also increases the dividend payouts. For this purpose, we replaced the board gender diversity measures with $F D 1, F D 2$, and $F D 3$. The outcomes are reported in Table 5 (Columns 7 and 8) using both ratios. DIVPR results suggest that female directors and dividend payouts are positively associated when the board has only one female $(F D 1=0.005, t$-stat $=1.660)$. However, when we increase the participation of females on the board to two, this further increases the dividend payouts $(F D 2=$ $0.009, t$-stat $=2.530)$. The most extreme influence occurs when the board has three or more female directors $(F D 3=$ $0.029, t$-stat $=5.616$ ). The results are consistent when we used DTA as dependent variable for one $(F D 1=0.001, t$-stat $=1.513)$, two $(F D 2=0.003, t$-stat $=2.219)$, and three or more female directors $(F D 3=0.005, t$-stat $=4.122)$, showing significant positive association with dividend payouts. ${ }^{8}$ The above findings provide support for $H 3$ that a subsequent increase in the number of the female also increases the dividend payouts. Theoretically, our findings are compatible with Kramer et al. (2007) and Kristie (2011), who suggested that having three or more females on the board provides the greatest impact. Empirically, our results also support previous studies (Ahmed \& Ali, 2017; Liu et al., 2014).

Furthermore, to test whether board gender diversity is expected to lead to higher dividends in SOEs, we divided the sample into SOEs and non-SOEs. If the firm was owned by the state or government, we considered it an SOE; otherwise, it was treated as a non-SOE. The results are presented in Table 5 (Columns 9 and 10) for SOEs, revealing a higher significant positive relationship between gender diversity and dividend payments. The results of DIVPR (FDP $=.066$, $t$-stat $=3.194)$ and DTA $(F D P=.021, t$-stat $=2.019)$ confirm that board gender diversity has a higher impact on the dividend payments of SOEs compared with non-SOEs (Columns 11 and 12), given the values for DIVPR $(F D P=$ $.019, t$-stat $=1.754)$ and $D T A(F D P=.002, t$-stat $=1.670)$. These findings provide support for $H 4$, and also partly support Lam et al. (2012) and Bradford et al. (2013), who showed that state-owned firms in China are associated with larger cash dividend payments.

\section{Endogeneity}

As everyone knows, CG researchers, especially those who deal with the structure of boards, face the possible problem of endogeneity. It can be argued that females are inclined to join the board in discrete groups, not randomly, which may be a result of biased coefficient estimations. Bilimoria and Piderit (1994) reported that it is the woman's choice that determines which firm's board she wants to join. There may also be a possibility that firms pay more dividends because of some other factors, for example, board structure, ownership structure, or some other economic firm variables other than gender diversity on the board. Thus, it may be possible that our findings are just a coincidence. To address potential endogeneity, we adopted various methods. To overcome the omitted variable, we use the instrumental variable (IV) approach. We used the lag of the explanatory variable for reverse causality. Finally, to address the problem of selective bias, we use the PSM approach.

\section{Reverse Causality}

Gul et al. (2011) and An and Zhang (2013) used the lag of gender diversity measures in their studies. To control for reverse causality, we used the lag of $t-1, t-2$, and $t-3$ years (Dittmann et al., 2010; Joecks et al., 2013), as female directors may require some time to understand the functions of the 
Table 6. Lag of Gender Diversity Measures.

\begin{tabular}{|c|c|c|c|c|c|c|}
\hline \multirow[b]{2}{*}{ Variable } & \multicolumn{6}{|c|}{ DIVPR } \\
\hline & $(\mathrm{I})$ & $(2)$ & (3) & (4) & (5) & (6) \\
\hline $\operatorname{LFDP}_{(t-3)}$ & $.074 * * *(6.252)$ & & & & & \\
\hline $\operatorname{LFDP}_{(t-2)}$ & & $.065 * * *(5.44 I)$ & & & & \\
\hline$L F D P_{(t-I)}$ & & & $.062^{* * * *}(5.632)$ & & & \\
\hline$F D D_{(t-3)}$ & & & & $.014 * * *(5.199)$ & & \\
\hline$F D D_{(t-2)}$ & & & & & $.015^{* * *}(5.45 \mathrm{I})$ & \\
\hline$F D D_{(t-1)}$ & & & & & & $.014 * * *(5.45 \mathrm{I})$ \\
\hline Controls, industry and year FE & YES & YES & YES & YES & YES & YES \\
\hline$R^{2}$ & .257 & .262 & .255 & .255 & .255 & .255 \\
\hline \multirow[t]{2}{*}{ Observations } & 21,417 & 22,140 & 23,139 & 21,417 & 22,140 & 23,139 \\
\hline & \multicolumn{6}{|c|}{ DTA } \\
\hline Variable & $(\mathrm{I})$ & $(2)$ & (3) & $(4)$ & $(5)$ & (6) \\
\hline$F D P_{(t-3)}$ & $.003 * * *(2.858)$ & & & & & \\
\hline$F D P_{(t-2)}$ & & $.003 * * *(2.883)$ & & & & \\
\hline$F D P_{(t-1)}$ & & & $.003 * * *(3.370)$ & & & \\
\hline$F D D_{(t-3)}$ & & & & $.001 * *(2.508)$ & & \\
\hline$F D D_{(t-2)}$ & & & & & $.00 I^{* * *}(3.540)$ & \\
\hline$F D D_{(t-1)}$ & & & & & & $.001 * *(3.503)$ \\
\hline Controls, industry and year FE & YES & YES & YES & YES & YES & YES \\
\hline$R^{2}$ & .185 & .184 & .182 & .185 & .185 & .185 \\
\hline Observations & 21,417 & 22,140 & 23,139 & 21,417 & 22,140 & 23,139 \\
\hline
\end{tabular}

Note. Variables are as defined in Table I. $t$-statistics are reported in parentheses.

$*, * *$, and $* * *$ indicate significance at the $10 \%, 5 \%$, and $1 \%$ levels, respectively.

board and to perform their monitoring roles successfully. Table 6 reports that board gender diversity and dividend payouts are positively associated, which provides further support for our results.

\section{Two-Stage Least Squares}

The results of our study are compatible with the findings of Chen et al. (2017), but still face the problem of endogeneity. One endogeneity problem is the problem of omitted variables. Although our study utilizes year and industry dummies to control the potential determinants of dividend payouts, they could be still affected by some unobservable variables. We therefore need to find an appropriate IV that has no direct relation with the policy of dividend payment, but that should be able to influence gender diversity directly. We used the lag $(L F D P)$, then the industry average of $F D P(I A F D P)$ of gender diversity measures, and finally both lagged values and $I A F D P$ as an instrument variable (Chen et al., 2015; Lin et al., 2013). Numerous researches have utilized the industrial average to build an instrument variable (Chen, 2015; Huang \& Mazouz, 2018; Kim et al., 2017; Liu et al., 2014). Based on these studies, we consider that these IVs are suitable for our study.

The findings of the first-stage regressions are reported in Panel A of Table 7, by using the dependent variables as $F D P$ and $F D D$ after including the above instruments as independent variables and all the control variables used in the main regression. For the sake of brevity, we report only the coefficients of main variables. FDP and $F D D$ are significantly positively correlated with $I A F D P$ and $L F D P$ consistent with the rationale of instruments and demonstrate that our instruments are valid (Ye et al., 2019). In Panel B using DIVPR and DTA as dependent variables and gender diversity measures $F D P$ and $F D D$ as independent variables, we run the second-stage regressions. The findings in Table 7 verify that the results are consistent with our main hypothesis.

\section{Propensity Score Matching (PSM)}

Self-selection bias may be another possible issue in the validity of our least squares outcomes. This posits that heterogeneous boards and non-heterogeneous boards have different characteristics, and that it is possible that, due to these characteristics, firms pay a higher dividend, instead of female directors' presence on the board (Usman et al., 2019). To resolve this problem, we followed the literature (Chen et al., 2017; Faccio et al., 2016; Liu, 2018) and employed PSM. ${ }^{9}$ This was achieved first by using the logit model to estimate the probability that the company will hire female directors, including the same control variables used in the main regression. Using this method, a control group (i.e., companies without female directors) was determined for each company related to the treatment group 
Table 7. Two-Stage Least Square (2SLS) Regression.

\begin{tabular}{|c|c|c|c|c|}
\hline \multicolumn{5}{|l|}{ Panel A: First-stage regression } \\
\hline \multirow[b]{2}{*}{ Variable } & \multicolumn{2}{|c|}{ Dependent variable $=$ FDP } & \multicolumn{2}{|c|}{ Dependent variable $=$ FDD } \\
\hline & ( 1 ) & $(2)$ & (3) & (4) \\
\hline IAFDP & $0.096 * * *(3.856)$ & & $0.016 * * *(2.898)$ & \\
\hline LFDP & & $0.053^{* * *}(4.712)$ & & $0.057^{* * *}(3.693)$ \\
\hline Controls, industry and year FE & YES & YES & YES & YES \\
\hline Observations & 24,142 & 23,139 & 24,142 & 23,139 \\
\hline \multicolumn{5}{|l|}{ Panel B: Second-stage regression } \\
\hline & \multicolumn{2}{|c|}{ DIVPR } & \multicolumn{2}{|c|}{ DTA } \\
\hline Variable & $(\mathrm{l})$ & $(2)$ & (3) & $(4)$ \\
\hline FDP & $0.076^{* * *}(5.853)$ & & $0.006 * * *(4.647)$ & \\
\hline FDD & & $0.028 * * *(6.145)$ & & $0.002^{* * *}(4.15 \mathrm{I})$ \\
\hline Controls, industry and year FE & YES & YES & YES & YES \\
\hline$R^{2}$ & .254 & .252 & .242 & .241 \\
\hline Observations & 23,139 & 23,139 & 23,139 & 23,139 \\
\hline
\end{tabular}

Note. Variables are as defined in Table I. $t$-statistics are reported in parentheses.

$*$, **, and $* * *$ indicate significance at the $10 \%, 5 \%$, and $1 \%$ levels, respectively.

Table 8. Endogeneity.

\begin{tabular}{|c|c|c|c|c|}
\hline \multirow[b]{2}{*}{ Variable } & \multicolumn{2}{|c|}{ DIVPR } & \multicolumn{2}{|c|}{ DTA } \\
\hline & (I) & $(2)$ & (3) & (4) \\
\hline \multicolumn{5}{|c|}{ Panel A: Propensity score matching (PSM) } \\
\hline FDP & $0.039 * * *(3.431)$ & & $0.003 * * *(2.825)$ & \\
\hline FDD & & $0.007^{* *}(2.3 \mid 2)$ & & $0.001 * *(2.169)$ \\
\hline Controls, industry and year FE & YES & YES & YES & YES \\
\hline$R^{2}$ & 0.262 & 0.262 & 0.261 & 0.260 \\
\hline \multicolumn{5}{|l|}{ Panel B: Fixed-effect method (FEM) } \\
\hline FDP & $0.010 * * *(4.178)$ & & $0.023 * *(2.273)$ & \\
\hline FDD & & $0.001 * *(1.992)$ & & $0.006 *(1.790)$ \\
\hline Controls, industry and year FE & YES & YES & YES & YES \\
\hline$R^{2}$ & .117 & .117 & .122 & .122 \\
\hline
\end{tabular}

Note. Variables are as defined in Table I. $t$-statistics are reported in parentheses.

$*$, **, and $* * *$ indicate significance at the $10 \%, 5 \%$, and $1 \%$ levels, respectively.

(i.e., companies with female directors). The control group was considered to have no distinct characteristics other than gender diversity. The PSM results are listed in Table 8 (Panel A). The coefficients of $F D P$ and $F D D$ are consistent with previous findings.

\section{Fixed-Effect Method (FEM)}

There is a critical issue with the ordinary least squares methodology, which is endogeneity. One might argue that the association between female directors and dividend payouts may be affected by unobservable characteristics at the company level. Hence, after including the company's fixed effect and the company's year fixed effect, the model was estimated again. The findings are reported in Table 8
(Panel B) and confirm our main results and demonstrate that board gender diversity increases dividend payouts. To control for heteroskedasticity and auto-correlation, we also ran fixed effect regression with robust standard errors. The results also provide support for our previous findings. ${ }^{10}$

\section{Robustness Tests}

\section{Gender Diversity, Financial Crisis, and Dividend Payouts}

Our sample period was from 2003 to 2017, so it includes the global financial crisis that started in 2007. Although the exact beginning of the crisis is still controversial in academia (González, 2016), there is no doubt that it had an 
Table 9. Robustness Tests.

\begin{tabular}{|c|c|c|c|c|}
\hline \multirow[b]{2}{*}{ Variable } & \multicolumn{2}{|c|}{ DIVPR } & \multicolumn{2}{|c|}{ DTA } \\
\hline & $(\mathrm{I})$ & $(2)$ & (3) & $(4)$ \\
\hline \multicolumn{5}{|c|}{ Panel A: Gender diversity, financial crisis and dividend payouts } \\
\hline FDP & $0.045^{* * *}(4.167)$ & & $0.004 * * *(3.402)$ & \\
\hline FDD & & $0.009 * * *(3.335)$ & & $0.001 * * *(2.736)$ \\
\hline CRISISD & $-0.014 *(-1.676)$ & $-0.014 *(-1.688)$ & $-0.002^{* * *}(-2.908)$ & $-0.002 * * *(-2.918)$ \\
\hline Controls, industry and year FE & YES & YES & YES & YES \\
\hline$R^{2}$ & .154 & .154 & .142 & .142 \\
\hline Observations & 24,142 & 24,142 & 24,142 & 24,142 \\
\hline \multicolumn{5}{|l|}{ Panel B: Blau and Shannon index } \\
\hline$F B I$ & $0.037 * * *(4.445)$ & & $0.003 * * *(3.557)$ & \\
\hline FSI & & $0.024 * * *(4.316)$ & & $0.002 * * *(3.448)$ \\
\hline Controls, industry and year FE & YES & YES & YES & YES \\
\hline$R^{2}$ & .255 & .254 & .242 & .242 \\
\hline Observations & 24,142 & 24,142 & 24,142 & 24,142 \\
\hline
\end{tabular}

Note. Variables are as defined in Table I. $t$-statistics are reported in parentheses.

$*, * *$, and $* * *$ indicate significance at the $10 \%, 5 \%$, and $1 \%$ levels, respectively.

influence on most of the companies (Fahlenbrach \& Stulz, 2011). Here, our main focus is on whether gender diversity on the board still has a positive impact on dividend payouts after controlling for the impact of financial crises. For this, we created a dummy variable (CRISISD) as a measure for the financial crisis when company exists in 2007 and 2008, it is equal to 1; otherwise 0 (An \& Zhang, 2013). In Table 9 (Panel A), our results are similar with the outcomes of Floyd et al. (2015) in that although firms still paid dividends, the dividend payout ratio continued to decline gradually during the financial crisis. We also report that the $F D P$ and $F D D$ still had a significant positive relationship with dividend payouts. Therefore, our conclusions are not affected by the financial crisis.

\section{Blau Index and Shannon Index}

Based on the recent literature, we used two comprehensive (alternative) proxies for gender diversity, that is, the Blau index (FBI) (Blau, 1977) and the Shannon index (FSI) (Shannon, 1948). The outcomes are reported in Table 9 (Panel B), which also shows the positive relationship of FBI and FSI with dividend payouts. Besides these comprehensive measures, we also used other measures of gender diversity such as the number of female directors (FNUM), the lag of numbers of female directors ( $L F N U M)$, female CEOs (FCEO), and the lag of female CEOs ( $L F C E O)$. The results remain robust. For the sake of brevity, we do not report the results.

\section{Further Tests}

Alternative estimation model. In our baseline regression analysis, we used the least square analysis. Hence, to eradicate the bias of measuring methods, we used the logit regression model by using dividend dummy (DD) as a dependent variable. Changing the estimation model does not alter our key conclusions. For the sake of brevity, we do not reveal the findings.

Alternative dependent variable. We also used DSAL (ratio of dividend over sales) as a dependent variable in the least squares method. The outcomes remain robust and corresponding results are not shown for brevity.

\section{Summary and Conclusions}

Our study provides a novel insight and finds reliable evidence that the involvement of female directors on the board has a positive influence on dividend payment by controlling the CG and other firm-related variables such as size of the firm, board size, leverage, and cash flow. The outcomes of our study are also in accordance with Adams and Ferreira (2009), who suggested that female participation may improve agency problems by enhancing the monitoring ability of boards. The results also support critical mass theory, which suggests that three or more females on the board have more influence on dividend payments compared with only their token participation (Kanter, 1977; Kristie, 2011). The results also show that independent female directors increase the dividend payments of firms, whereas female executive directors have no impact on dividend payouts, indicating that females are not a uniform group. Furthermore, we show that gender diversity has a greater influence on the dividends payouts of SOEs than non-SOEs (Wang et al., 2011).

The findings of our study have several implications for policy, practice, and theory. The results support the argument that the effectiveness of the board is improved due to female participation. The policy implications for our study 
are exhibited in two aspects. The first aspect concerns the gender diversity of the board. Adams and Kirchmaier (2016) reported that for the implementation of gender quotas in listed companies, European countries frequently announce relevant laws. Our research indicates that female directors may have value in relation to $\mathrm{CG}$, which is relevant to policymakers. The second aspect concerns the career development of females. To resolve the agency problems in CG, gender diversity on the boards is likely to offer a wide range of views on such issues. Therefore, to encourage career development, policymakers must initiate some professional training to improve skills and construct a rational competitive atmosphere for females.

The practical implications of our article concern its support for the belief that gender diversity is a vital issue for CG. The findings suggest that female participation on the board may expand the firm-level governance in emerging economies, where investors' protection is inclined to be weak. Our study highlights the diversity practice of China at the boardroom level and also guides the regulatory bodies of China on this issue. As due to this growing concern, a better understanding for the role of female director in improving CG will help academics, policymakers, and regulators in decision making about the value of female directors. Regarding theoretical implications, our study extends agency theory by signifying that the female directors on the board improve its effectiveness. Furthermore, our results also contribute new insights regarding how the governance role of female directors is affected by country-specific institutional factors and provide support to the recommendations of regulatory bodies around the world on gender diversity in the boardroom. More precisely, gender diversity on board can strengthen China's poor governance system.

Our study also has some caveats, which may provide fruitful insights for future research. First, due to data limitations, we were unable to include other characteristics of female directors, such as their experience, education, and expertise. Second, we encountered only a few institutional factors in examining the female governance role. Future studies can also include other within country institutional factors such as concentrated ownership, family-owned firms, and developedregion firms, and can observe the results by differentiating between publicly and privately owned listed companies. Third, we were unable to use company buybacks (share repurchase) in our study due to data unavailability. Further studies may also include this. Finally, future studies can also include the effect of mergers and acquisition (M\&A) deals on the relationship between gender diversity and dividend payouts.

\section{Appendix}

Table AI. Sample Distribution by Year and Industry.

\begin{tabular}{|c|c|c|c|c|c|c|c|c|c|c|c|c|c|c|c|c|}
\hline \multirow{2}{*}{$\begin{array}{l}\text { Industry } \\
\text { code }\end{array}$} & \multicolumn{15}{|c|}{ Year } & \multirow{2}{*}{$\begin{array}{l}\text { Total by } \\
\text { industry }\end{array}$} \\
\hline & 2003 & 2004 & 2005 & 2006 & 2007 & 2008 & 2009 & 2010 & 2011 & 2012 & 2013 & 2014 & 2015 & 2016 & 2017 & \\
\hline A & 23 & 28 & 29 & 29 & 32 & 31 & 30 & 39 & 40 & 38 & 39 & 39 & 43 & 43 & 43 & 526 \\
\hline B & 19 & 23 & 23 & 24 & 31 & 30 & 39 & 49 & 53 & 58 & 59 & 63 & 67 & 69 & 69 & 676 \\
\hline $\mathrm{CO}$ & 49 & 50 & 51 & 55 & 56 & 57 & 62 & 73 & 83 & 85 & 89 & 96 & 101 & 113 & 125 & 1,145 \\
\hline $\mathrm{Cl}$ & 44 & 51 & 52 & 55 & 57 & 59 & 58 & 61 & 67 & 74 & 74 & 77 & 78 & 80 & 86 & 973 \\
\hline $\mathrm{C} 2$ & 2 & 3 & 4 & 4 & 3 & 5 & 6 & 8 & 9 & 13 & 13 & 14 & 14 & 21 & 31 & 150 \\
\hline C3 & 22 & 24 & 24 & 28 & 28 & 32 & 33 & 39 & 43 & 41 & 44 & 44 & 46 & 50 & 54 & 552 \\
\hline C4 & 112 & 119 & 118 & 126 & 134 & 140 & 151 & 194 & 225 & 242 & 245 & 254 & 268 & 291 & 326 & 2,945 \\
\hline C5 & 110 & 119 & $12 \mid$ & 133 & 154 & 164 & 191 & 262 & 308 & 351 & 357 & 373 & 409 & 456 & 534 & 4,042 \\
\hline C6 & 100 & 109 & 113 & 117 & 128 & 133 & 146 & 168 & 180 & 186 & 187 & 199 & 210 & 221 & 239 & 2,436 \\
\hline$C 7$ & 103 & 114 & 116 & 110 & 124 & 134 & 150 & 207 & 251 & 268 & 274 & 298 & 326 & 370 & 410 & 3,255 \\
\hline C8 & 73 & 86 & 84 & 88 & 88 & 93 & 104 & 125 & 139 & 138 & 136 & 145 & 158 & 173 & 207 & I,837 \\
\hline C9 & 43 & 49 & 48 & 51 & 57 & 60 & 63 & 77 & 81 & 90 & 96 & 104 & 109 & 123 & 146 & I, I97 \\
\hline D & 55 & 64 & 62 & 65 & 68 & 69 & 66 & 73 & 78 & 100 & 99 & 109 & 115 & 126 & 144 & I,293 \\
\hline$E$ & 22 & 24 & 24 & 30 & 33 & 32 & 40 & 39 & 47 & 59 & 62 & 64 & 75 & 86 & 94 & 731 \\
\hline $\mathrm{F}$ & 45 & 45 & 49 & 54 & 55 & 57 & 63 & 70 & 73 & 77 & 79 & 79 & 83 & 86 & 94 & 1,009 \\
\hline G & 35 & 40 & 41 & 45 & 48 & 55 & 74 & 100 & 120 & 119 & 130 & 137 & 154 & 208 & 242 & $\mathrm{I}, 548$ \\
\hline $\mathrm{H}$ & 87 & 89 & 91 & 92 & 88 & 89 & 95 & 108 & 119 & 146 & 148 & 146 & 148 & 150 & 158 & $\mathrm{I}, 754$ \\
\hline J & 56 & 57 & 57 & 60 & 63 & 71 & 83 & 112 & 115 & $|3|$ & 124 & 120 & 123 & 118 & 116 & 1,406 \\
\hline K & 16 & 19 & 19 & 21 & 25 & 28 & 33 & 44 & 51 & 37 & 39 & 46 & 56 & 77 & 102 & 613 \\
\hline L & 4 & 3 & 3 & 4 & 5 & 6 & 9 & 12 & 18 & 23 & 24 & 28 & 38 & 46 & 56 & 279 \\
\hline M & 65 & 64 & 64 & 67 & 62 & 64 & 63 & 57 & 57 & 28 & 29 & 29 & 31 & 28 & 29 & 737 \\
\hline Total by year & I,085 & 1,180 & 1,193 & I,258 & 1,339 & 1,409 & 1,559 & 1,917 & 2,157 & 2,304 & 2,347 & 2,464 & 2,652 & 2,935 & 3,305 & 29,104 \\
\hline
\end{tabular}

Note. $\mathrm{A}=$ agri-business; $\mathrm{B}=$ mining; $\mathrm{C} 0=$ drinks and food; $\mathrm{Cl}=$ footwear, textile, and clothing; $\mathrm{C} 2=$ wood processing and furniture; $\mathrm{C} 3=$ printing and papermaking; $C 4=$ chemical, petroleum, and plastic; $C 5=$ electronic industry; $C 6=$ non-metallic and metal industry; $C 7=$ instruments, equipment, and machinery; $\mathrm{C} 8$ = medicine industry; $\mathrm{C} 9=$ others; $\mathrm{D}=$ public utilities; $\mathrm{E}=$ construction; $F=$ warehousing and transportation; $\mathrm{G}=$ information technology; $\mathrm{H}=$ wholesale and retail; $\mathrm{J}=$ real estate; $\mathrm{K}=$ social services; $\mathrm{L}=$ culture and communication; $\mathrm{M}=$ conglomerates 


\section{Declaration of Conflicting Interests}

The author(s) declared no potential conflicts of interest with respect to the research, authorship, and/or publication of this article.

\section{Funding}

The author(s) disclosed receipt of the following financial support for the research, authorship, and/or publication of this article: This work was supported by the Natural Science Foundation of China (Grants 11631013, 11971372, and 11801433).

\section{ORCID iDs}

Xianghui Yuan (iD https://orcid.org/0000-0003-1466-5268

Jinkai Zhao (iD https://orcid.org/0000-0002-9039-2196

\section{Notes}

1. http://www.gender-map.com/

2. The study of McGuinness et al. (2015) focused on other impacts of salient demographics and characteristics on corporate dividend policy (e.g., CEO age, CEO tenure, CEO duality). However, this study excluded and provided no contributions regarding (a) the significant contributions of females in reducing agency problems (by providing robust evidence); (b) the effect of independent versus executive female directors; (c) the critical mass of female directors; and (d) the ownership structure.

3. Saeed and Sameer (2017) suggested that women directors on boards use conservative policies and reported significant negative results using data from emerging economies.

4. Chinese financial regulators have adopted different strategies to urge listed companies to increase cash dividend distributions with the objective of reducing agency problems since the 1990s. These regulators have more control over state-controlled firms.

5. Wang et al. (2011) reported that a part of the dividends is paid by investors to the state in the form of taxes.

6. These results are available upon request.

7. The results are also reported in Table 4 and show that none of the VIF values exceed 2.443, which is well below the accepted level of 10 (Gujrati, 2003).

8. We have also checked the results by adding FD1, FD2, and FD3 in separate regressions and found the same results as before. These results are available upon request.

9. Specifically, we use this method without any replacement. Matching without any replacement means that the same firm with one or more female directors can only be matched with only one all-male director company.

10. A fixed-effect regression with robust standard errors deals with possible heterogeneity and auto-correlation. Our conclusions are robust; for the sake of brevity, the corresponding results are not shown.

\section{References}

Adams, R. B., \& Ferreira, D. (2009). Women in the boardroom and their impact on governance and performance. Journal of Financial Economics, 94(2), 291-309. https://doi. org/10.1016/j.jfineco.2008.10.007
Adams, R. B., \& Kirchmaier, T. (2016). Women on boards in finance and STEM industries. American Economic Review, 106(5), 277-281. https://doi.org/10.1257/aer.p20161034

Adams, R. B., \& Mehran, H. (2012). Bank board structure and performance: Evidence from large bank holding companies. Journal of Financial Intermediary, 21(2), 243-267.

Adjaoud, F., \& Ben-Amar, W. (2010). Corporate governance and dividend policy: Shareholders' protection or expropriation? Journal of Business Finance \& Accounting, 37(5-6), 648-667. https://doi.org/10.1111/j.1468-5957.2010.02192.x

Agarwal, S., Qian, W. L., Reeb, D. M., \& Sing, T. F. (2016). Playing the boys game: Golf buddies and board diversity. American Economic Review, 106(5), 272-276. https://doi.org/10.1257/ aer.p20161033

Ahmed, A., \& Ali, S. (2017). Boardroom gender diversity and stock liquidity: Evidence from Australia. Journal of Contemporary Accounting \& Economics, 13(2), 148-165. https://doi.org/10.1016/j.jcae.2017.06.001

Ain, Q. U., Yuan, X., Javaid, H. M., Usman, M., \& Haris, M. (2020). Female directors and agency costs: Evidence from Chinese listed firms. International Journal of Emerging Markets. Advance online publication. https://doi.org/10.1108/ IJOEM-10-2019-0818

An, H., \& Zhang, T. (2013). Stock price synchronicity, crash risk, and institutional investors. Journal of Corporate Finance, 21, 1-15. https://doi.org/10.1016/j.jcorpfin.2013.01.001

Areddy, J., Bai, L., \& Leow, J. (2008). China seeks to lift market by raising stake in major banks. The Wall Street Journal Eastern Edition, 68, Article 252.

Bae, S. C., Chang, K., \& Kang, E. (2012). Culture, corporate governance and dividend policy: International evidence. The Journal of Financial Research, 35(2), 289-316.

Bathala, C. T., \& Rao, R. P. (1995). The determinants of board composition: An agency theory perspective. Managerial and Decision Economics, 16(1), 59-69.

Beck, T., \& Levine, R. (2004). Stock markets, banks, and growth: Panel evidence. Journal of Banking \& Finance, 28(3), 423442. https://doi.org/10.1016/S0378-4266(02)00408-9

Benito, A., \& Young, G. (2003). Hard times or great expectations? Dividend omissions and dividend cuts by UK firms. Oxford Bulletin of Economics and Statistics, 65(5), 531-555.

Ben-Nasr, H. (2015). Government ownership and dividend policy: Evidence from newly privatised firms. Journal of Business Finance \& Accounting, 42(5-6), 665-704. https://doi.org $/ 10.1111 / \mathrm{jbfa} .12115$

Bernardi, R. A., \& Arnold, D. F. (1997). An examination of moral development within public accounting by gender, staff level, and firm. Contemporary Accounting Research, 14, 653-668. https://doi.org/10.1111/j.1911-3846.1997.tb00545.x

Bilimoria, D., \& Piderit, S. K. (1994). Board committee membership_Effects of sex-based bias. Academy of Management Journal, 37(6), 1453-1477. https://doi.org/10.2307/256795

Blanchard, O., \& Shleifer, A. (2000). Federalism with and without political centralisation: China versus Russia (NBER Working Paper No. 7616). National Bureau of Economic Research.

Blau, P. M. (1977). Inequality and heterogeneity. The Free Press.

Bradford, W., Chen, C., \& Zhu, S. (2013). Cash dividend policy, corporate pyramids, and ownership structure: Evidence from China. International Review of Economics \& Finance, 27, 445-464. https://doi.org/10.1016/j.iref.2013.01.003 
Brav, A., Graham, J. R., Harvey, C. R., \& Michaely, R. (2005). Payout policy in the 21st century. Journal of Financial Economics, 77(3), 483-527. https://doi.org/10.1016/j.jfineco.2004.07.004

Buge, M., Egeland, M., Kowalski, P., \& Sztajerowska, M. (2013). State-owned enterprises in the global economy: Reason for concern? http://www.voxeu.org/article/state-owned-enterprises-global-economy-reason-concern

Bugeja, M., Matolcsy, Z., \& Spiropoulos, H. (2016). The association between gender-diverse compensation committees and CEO compensation. Journal of Business Ethics, 139(2), 375-390. https://doi.org/10.1007/s10551-015-2660-y

Byoun, S., Chang, K., \& Kim, Y. (2013). Does corporate board diversity affect corporate payout policy? [Unpublished working paper]. Baylor University.

Byoun, S., Chang, K., \& Kim, Y. S. (2016). Does corporate board diversity affect corporate payout policy? Asia-Pacific Journal of Financial Studies, 45(1), 48-101. https://doi.org/10.1111/ ajfs. 12119

Campbell, K., \& Minguez-Vera, A. (2007). Gender diversity in the boardroom and firm financial performance. Journal of Business Ethics, 83, 435-451.

Carlson, R. (1972). Understanding women-Implications for personality theory and research. Journal of Social Issues, 28(2), 17-32. https://doi.org/10.1111/j.1540-4560.1972.tb00015.x

Carter, D. A., Simkins, B. J., \& Simpson, W. G. (2003). Corporate governance, board diversity, and firm value. Finance Review, $38,33-53$.

Carter, F., D’Souza Simkins, B. J., \& Simpson, W. G. (2010). The gender and ethnic diversity of US Boards and Board Committees and firm financial performance. Corporate Governance: An International Review, 18(5), 396-414.

Catalyst. (2016). 2016 Catalyst census: Women and men board directors.

Catalyst. (2017). Women on corporate boards globally.

Chae, J., Kim, S., \& Lee, E. J. (2009). How corporate governance affects payout policy under agency problems and external financing constraints. Journal of Banking \& Finance, 33(11), 2093-2101. https://doi.org/10.1016/j.jbankfin.2009.05.003

Chay, J. B., \& Suh, J. (2009). Payout policy and cash-flow uncertainty. Journal of Financial Economics, 93(1), 88-107. https:// doi.org/10.1016/j.jfineco.2008.12.001

Chen, J., Leung, W. S., \& Goergen, M. (2017). The impact of board gender composition on dividend payouts. Journal of Corporate Finance, 43, 86-105. https://doi.org/10.1016/j.jcorpfin.2017.01.001

Chen, T. (2015). Institutions, board structure, and corporate performance: Evidence from Chinese firms. Journal of Corporate Finance, 32, 217-237. https://doi.org/10.1016/j.jcorpfin.2014 .10 .009

Chen, X., Cheng, Q., \& Wang, X. (2015). Does increased board independence reduce earnings management? Evidence from recent regulatory reforms. Review of Accounting Studies, 20(2), 899-933. https://doi.org/10.1007/s11142-015-9316-0

Cumming, D., Leung, T. Y., \& Rui, O. (2015). Gender diversity and securities fraud. Academy of Management Journal, 58(5), 1572-1593. https://doi.org/10.5465/amj.2013.0750

DeAngelo, H., DeAngelo, L., \& Stulz, R. M. (2006). Dividend policy and the earned/contributed capital mix: A test of the lifecycle theory. Journal of Financial Economics, 81(2), 227-254. https://doi.org/10.1016/j.jfineco.2005.07.005
Denis, D. J., \& Osobov, I. (2008). Why do firms pay dividends? International evidence on the determinants of dividend policy. Journal of Financial Economics, 89(1), 62-82. https://doi. org/10.1016/j.jfineco.2007.06.006

Dittmann, I., Maug, E., \& Schneider, C. (2010). Bankers on the boards of German firms: What they do, what they are worth, and why they are (still) there. Review of Finance, 14(1), 35-71. https://doi.org/10.1093/rof/rfp007

Du, X. Q. (2014). Does religion mitigate tunneling? Evidence from Chinese Buddhism. Journal of Business Ethics, 125(2), 299-327. https://doi.org/10.1007/s10551-013-1917-6

Eagly, A. H., \& Crowley, M. (1986). Gender and helping-behavior-A meta-analytic review of the social psychological literature. Psychological Bulletin, 100(3), 283-308. https:// doi.org/10.1037/0033-2909.100.3.283

Easterbrook, F. H. (1984). Two agency-cost explanations of dividends. The American Economic Review, 74(4), 650-659.

Erhardt, N. L., Werbel, J. D., \& Shrader, C. B. (2003). Board of director diversity and firm financial performance. Corporate Governance-an International Review, 11(2), 102-111. https:// doi.org/10.1111/1467-8683.00011

Faccio, M., Marchica, M. T., \& Mura, R. (2016). CEO gender, corporate risk-taking, and the efficiency of capital allocation. Journal of Corporate Finance, 39, 193-209. https://doi. org/10.1016/j.jcorpfin.2016.02.008

Fahlenbrach, R., \& Stulz, R. M. (2011). Bank CEO incentives and the credit crisis. Journal of Financial Economics, 99(1), 11-26.

Fama, E. F. (1980). Agency problems and the theory of the firm. Journal of Political Economy, 88(2), 288-307. https://doi. org/10.1086/260866

Fama, E. F., \& French, K. R. (2001). Disappearing dividends: Changing firm characteristics or lower propensity to pay? Journal of Financial Economics, 60(1), 3-43. https://doi. org/10.1016/S0304-405x(01)00038-1

Fama, E. F., \& Jensen, M. C. (1983). Agency problems and residual claims. Journal of Law \& Economics, 26(2), 327-349. https:// doi.org/10.1086/467038

Field, A. P. (2005). Is the meta-analysis of correlation coefficients accurate when population correlations vary? Psychological Methods, 10(4), 444-467. https://doi.org/10.1037/1082-989x .10 .4 .444

Firth, M., Gao, J., Shen, J. H., \& Zhang, Y. Y. (2016). Institutional stock ownership and firms' cash dividend policies: Evidence from China. Journal of Banking \& Finance, 65, 91-107. https://doi.org/10.1016/j.jbankfin.2016.01.009

Floyd, E., Li, N., \& Skinner, D. J. (2015). Payout policy through the financial crisis: The growth of repurchases and the resilience of dividends. Journal of Financial Economics, 118(2), 299-316. https://doi.org/10.1016/j.jfineco.2015.08.002

Gilligan, C. (1977). In a different voice-Women's conceptions of self and of morality. Harvard Educational Review, 47(4), 481517. https://doi.org/10.17763/haer.47.4.g6167429416hg510

Glazer, N., \& Kristol, I. (1976). The American commonwealth. Basic Books.

González, F. (2016). Creditor rights, bank competition, and corporate investment during the global financial crisis. Journal of Corporate Finance, 37, 249-270.

Grossman, S. J., \& Hart, O. D. (1980). Takeover bids, the freerider problem, and the theory of the corporation. Bell Journal of Economics, 11(1), 42-64. https://doi.org/10.2307/3003400 
Grossman, S. J., \& Hart, O. D. (1986). The costs and benefits of ownership - A theory of vertical and lateral integration. Journal of Political Economy, 94(4), 691-719. https://doi. org/10.1086/261404

Gujrati, D. N. (2003). Basic econometrics (4th ed.). McGraw Hill.

Gul, F. A., Srinidhi, B., \& Ng, A. C. (2011). Does board gender diversity improve the informativeness of stock prices? Journal of Accounting \& Economics, 51(3), 314-338. https://doi. org/10.1016/j.jacceco.2011.01.005

Gul, F. A., Srinidhi, B., \& Tsui, J. S. (2008). Board diversity and the demand for higher audit effort. http://doi.org/10.2139/ ssrn. 1359450

Gulzar, M. A., Cherian, J., Hwang, J., Jiang, Y. S., \& Sial, M. S. (2019). The impact of board gender diversity and foreign institutional investors on the Corporate Social Responsibility (CSR) engagement of Chinese listed companies. Sustainability, 11(2), $1-19$.

Gyapong, E., Monem, R. M., \& Hu, F. (2016). Do women and ethnic minority directors influence firm value? Evidence from post-apartheid South Africa. Journal of Business Finance \& Accounting, 43(3-4), 370-413. https://doi.org/10.1111/ jbfa. 12175

He, W., \& Luo, J. H. (2018). Agency problems in firms with an even number of directors: Evidence from China. Journal of Banking \& Finance, 93, 139-150. https://doi.org/10.1016/j. jbankfin.2018.06.006

Hillman, A. J., Shropshire, C., \& Cannella, A. A. (2007). Organizational predictors of women on corporate boards. Academy of Management Journal, 50(4), 941-952.

Huang, W., \& Mazouz, K. (2018). Excess cash, trading continuity, and liquidity risk. Journal of Corporate Finance, 48, 275-291. https://doi.org/10.1016/j.jcorpfin.2017.11.005

Hunter, D. M., \& Sah, N. (2014). Cash is queen: Female CEOs' propensity to hoard cash. Working Paper, University of South Florida.

Institutional Shareholder Services. (2017). Gender parity on boards around the world. Harvard Law School Forum on Corporate Governance and Financial Regulation. https://corpgov.law. harvard.edu/2017/01/05/gender-parity-on-boards-around-theworld/

Jensen, G. R., Solberg, D. P., \& Zorn, T. S. (1992). Simultaneous determination of insider ownership, debt, and dividend policies. Journal of Financial and Quantitative Analysis, 27(2), 247-263. https://doi.org/10.2307/2331370

Jensen, M. C. (1986). Agency costs of free cash flow, corporatefinance, and takeovers. American Economic Review, 76(2), 323-329.

Jensen, M. C., \& Meckling, W. H. (1976). Theory of firmManagerial behavior, agency costs and ownership structure. Journal of Financial Economics, 3(4), 305-360. https://doi. org/10.1016/0304-405x(76)90026-X

Joecks, J., Pull, K., \& Vetter, K. (2013). Gender diversity in the boardroom and firm performance: What exactly constitutes a "critical mass?" Journal of Business Ethics, 118(1), 61-72. https://doi.org/10.1007/s10551-012-1553-6

Jonge, A. (2014). The glass ceiling that refuses to break: Women directors on the boards of listed firms in China and India. Women's Studies International Forum, 47, 326-338. https:// doi.org/10.1016/j.wsif.2014.01.008
Jurkus, A. F., Park, J. C., \& Woodard, L. S. (2011). Women in top management and agency costs. Journal of Business Research, 64(2), 180-186. https://doi.org/10.1016/j.jbusres.2009.12.010

Kandel, E., \& Lazear, E. P. (1992). Peer pressure and partnerships. Journal of Political Economy, 100(4), 801-817. https://doi. org/10.1086/261840

Kanter, R. M. (1977). Some effects of proportions on group life-Skewed sex-ratios and responses to token women. American Journal of Sociology, 82(5), 965-990. https://doi. org/10.1086/226425

Kim, K., Patro, S., \& Pereira, R. (2017). Option incentives, leverage, and risk-taking. Journal of Corporate Finance, 43, 1-18. https://doi.org/10.1016/j.jcorpfin.2016.12.003

Knyazeva, A., Knyazeva, D., \& Masulis, R. W. (2013). The supply of corporate directors and board independence. Review of Financial Studies, 26(6), 1561-1605. https:/doi.org/10.1093/ $\mathrm{rfs} / \mathrm{hht} 020$

Kramer, V. W., Konrad, A. M., Erkut, S., \& Hooper, M. J. (2007). Critical mass on corporate boards: Why three or more women enhance governance. National Association of Corporate Directors.

Kristie, J. (2011). The power of three. Dir, 35(5), 22-32.

Lai, K. M., Srinidhi, B., Gul, F. A., \& Tsui, J. S. J. C. A. R. (2017). Board gender diversity, auditor fees, and auditor choice, 34(3), 1681-1714.

Lam, K. C., Sami, H., \& Zhou, H. (2012). The role of cross-listing, foreign ownership and state ownership in dividend policy in an emerging market. China Journal of Accounting Research, 5(3), 199-216.

La Porta, R., Lopez-de-Silanes, F., Shleifer, A., \& Vishny, R. W. (2000). Agency problems and dividend policies around the world. Journal of Finance, 55(1), 1-33. https://doi. org/10.1111/0022-1082.00199

Levit, D., \& Malenko, N. (2016). The labor market for directors and externalities in corporate governance. Journal of Finance, 71(2), 775-808. https://doi.org/10.1111/jofi.12287

Li, W. J., \& Zhang, R. (2010). Corporate social responsibility, ownership structure, and political interference: Evidence from China. Journal of Business Ethics, 96(4), 631-645. https://doi. org/10.1007/s10551-010-0488-z

Lin, C., Ma, Y., Malatesta, P., \& Xuan, Y. H. (2013). Corporate ownership structure and the choice between bank debt and public debt. Journal of Financial Economics, 109(2), 517-534. https://doi.org/10.1016/j.jfineco.2013.03.006

Lintner, J. (1956). Distribution of incomes of corporations among dividends, retained earnings, and taxes. American Economic Review, 46(2), 97-118.

Liu, C. (2018). Are women greener? Corporate gender diversity and environmental violations. Journal of Corporate Finance, 52, 118-142. https://doi.org/10.1016/j.jcorpfin.2018.08.004

Liu, Y., Wei, Z. B., \& Xie, F. X. (2014). Do women directors improve firm performance in China? Journal of Corporate Finance, 28, 169-184. https://doi.org/10.1016/j.jcorpfin.2013.11.016

Man, C. K., \& Wong, B. (2013). Corporate governance and earnings management: A survey of literature. Journal of Applied Business Research, 292(2), 391-418.

McGuinness, P. B., Lam, K. C. K., \& Vieito, J. P. (2015). Gender and other major board characteristics in China: Explaining corporate dividend policy and governance. Asia Pacific Journal 
of Management, 32(4), 989-1038. https://doi.org/10.1007/ s10490-015-9443-y

McGuinness, P. B., Vieito, J. P., \& Wang, M. Z. (2017). The role of board gender and foreign ownership in the CSR performance of Chinese listed firms. Journal of Corporate Finance, 42, 75-99. https://doi.org/10.1016/j.jcorpfin.2016. 11.001

Menozzi, A., Urtiaga, M. G., \& Vannoni, D. (2012). Board composition, political connections, and performance in state-owned enterprises. Industrial and Corporate Change, 21(3), 671-698. https://doi.org/10.1093/icc/dtr055

Miller, T., \& Triana, M. D. (2009). Demographic diversity in the boardroom: Mediators of the board diversity-firm performance relationship. Journal of Management Studies, 46(5), 755-786. https://doi.org/10.1111/j.1467-6486.2009.00839.x

Morck, R., \& Steier, L. (2005). The global history of corporate governance: An introduction. In A history of corporate governance around the world: Family business groups to professional managers (pp. 1-64). University of Chicago Press.

Mustafa, A., Saeed, A., Awais, M., \& Aziz, S. (2020). BoardGender diversity, family ownership, and dividend announcement: Evidence from Asian emerging economies. Journal of Risk and Financial Management, 13(4), 62.

Nekhili, M., Gull, A. A., Chtioui, T., \& Radhouane, I. J. J. (2020). Gender-diverse boards and audit fees: What difference does gender quota legislation make? Journal of Business Finance \& Accounting, 47(1-2), 52-99.

Nguyen, P., Rahman, N., \& Zhao, R. Y. (2013). Ownership structure and divestiture decisions: Evidence from Australian firms. International Review of Financial Analysis, 30, 170-181. https://doi.org/10.1016/j.irfa.2013.08.003

Niederle, M., \& Vesterlund, L. (2007). Do women shy away from competition? Do men compete too much? Quarterly Journal of Economics, 122(3), 1067-1101. https://doi.org/10.1162/ qjec.122.3.1067

Nielsen, S., \& Huse, M. (2010). The contribution of women on boards of directors: Going beyond the surface. Corporate Governance-an International Review, 18(2), 136-148. https:// doi.org/10.1111/j.1467-8683.2010.00784.x

Osma, B. G. (2008). Board independence and real earnings management: The case of $\mathrm{R} \& \mathrm{D}$ expenditure. Corporate Governance-an International Review, 16(2), 116-131. https:// doi.org/10.1111/j.1467-8683.2008.00672.x

Post, C., \& Byron, K. (2015). Women on boards and firm financial performance: A meta-analysis. Academy of Management Journal, 58(5), 1546-1571. https://doi.org/10.5465/amj .2013 .0319

Pucheta-Martinez, M. C., \& Bel-Oms, I. (2016). The board of directors and dividend policy: The effect of gender diversity. Industrial and Corporate Change, 25(3), 523-547. https://doi. org/10.1093/icc/dtv040

Rose, C. (2007). Does female board representation influence firm performance? The Danish evidence. Corporate Governance-an International Review, 15(2), 404-413. https://doi.org/10.1111/ j.1467-8683.2007.00570.x
Rozeff, M. S. (1982). Growth, beta and agency costs as determinants of dividend payout ratios. Journal of Financial Research, 53(3), 249-259.

Saeed, A., Belghitar, Y., \& Yousaf, A. (2016). Firm-level determinants of gender diversity in the boardrooms: Evidence from some emerging markets. International Business Review, 25(5), 1076-1088. https://doi.org/10.1016/j.ibusrev.2016.01.002

Saeed, A., \& Sameer, M. (2017). Impact of board gender diversity on dividend payments: Evidence from some emerging economies. International Business Review, 26(6), 1100-1113. https://doi.org/10.1016/j.ibusrev.2017.04.005

Setia-Atmaja, L. (2010). Dividend and debt policies of family controlled firms: The impact of board independence. International Journal of Managerial Finance, 6(2), 128-142.

Shannon, C. E. (1948). A mathematical theory of communication. Bell System Technical Journal, 27(3), 379-423. https://doi. org/10.1002/j.1538-7305.1948.tb01338.x

Shleifer, A., \& Vishny, R. W. (1997). A survey of corporate governance. Journal of Finance, 52(2), 737-783. https://doi. org/10.1111/j.1540-6261.1997.tb04820.x

Sila, V., Gonzalez, A., \& Hagendorff, J. (2016). Women on board: Does boardroom gender diversity affect firm risk? Journal of Corporate Finance, 36, 26-53. https://doi.org/10.1016/j.jcorpfin.2015.10.003

Spangler, E., Gordon, M. A., \& Pipkin, R. M. (1978). Token women: An empirical test of Kanter's hypothesis. American Journal of Sociology, 84(1), 160-170.

Trinh, V. Q., Cao, N. D., Dinh, L. H., \& Nguyen, H. N. (2020). Boardroom gender diversity and dividend payout strategies: Effects of mergers deals. International Journal of Finance and Economics, 1-22. https://doi.org/10.1002/ijfe.2106

Usman, M., Farooq, M., Zhang, J., Dong, N. Y., \& Makki, M. (2019). Women on boards and CEO pay-performance link. International Journal of Manpower, 40, 1171-1200. https:// doi.org/10.1108/IJM-04-2017-0056

Usman, M., Zhang, J. R., Wang, F. J., Sun, J. Q., \& Makki, M. A. M. (2018). Gender diversity in compensation committees and CEO pay: Evidence from China. Management Decision, 56(5), 1065-1087.

Wang, K. T., \& Shailer, G. (2012). Government control and performance criteria for Chinese listed corporations. Paper presented at the 24th Australasian Finance and Banking Conference.

Wang, X., Manry, D., \& Wandler, S. (2011). The impact of government ownership on dividend policy in China. Advances in Accounting, 27, 366-372.

World Trade Organization. (2015). International trade statistics. https://www.wto.org/english/res_e/statis_e/its2015e/its2015 e.pdf

Ye, D., Deng, J., Liu, Y., Szewczyk, S. H., \& Chen, X. (2019). Does board gender diversity increase dividend payouts? Analysis of global evidence. Journal of Corporate Finance, 58, 1-26. https://doi.org/10.1016/j.jcorpfin.2019.04.002

Zahra, S. A., \& Pearce, J. A. (1989). Boards of directors and corporate financial performance-A review and integrative model. Journal of Management, 15(2), 291-334. https://doi. org/10.1177/014920638901500208 